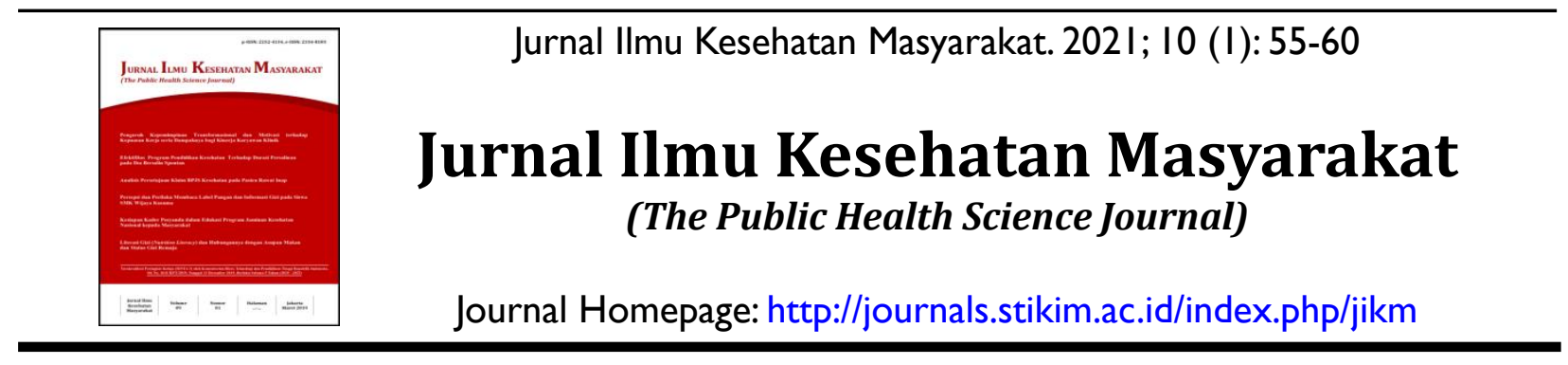

\title{
Efektifitas Promosi Kesehatan Dalam Deteksi Dini Ca Mammae pada Remaja
}

\author{
Rosa Susanti ${ }^{1}$, Zulaika $^{2}$ \\ IProgram Studi DIII Kebidanan, 2Program Studi DIII Administrasi Rumah Sakit \\ Fakultas Kesehatan Universitah MH. Thamrin, \\ Jl. Raya Pondok Gede No. 23-25 Kramat Jati - Jakarta Timur I3550 \\ Email: rosasusanti36@gmail.com', zulaikafiona@gmail.com²
}

\begin{abstract}
Abstrak
Angka kejadian penyakit kanker di Indonesia berada pada urutan ke-8 di Asia Tenggara, sedangkan di Asia berada pada urutan ke-23. Di Indonesia Angka kejadian tertinggi untuk perempuan adalah kanker payudara sebesar 42, I//00.000 penduduk dengan rata-rata kematian $17 / 100.000$. Promosi kesehatan merupakan upaya yang dapat dilakukan untuk menyebarluaskan informasi mengenai deteksi dini ca mammae. Tujuan pada penelitian ini untuk mengetahui efektifitas promosi kesehatan dalam deteksi dini Ca Mammae pada remaja dengan menggunakan video, leafleat dan tanpa media. Populasi pada penelitian ini adalah siswi SMKN 57, jumlah sampel sebanyak 90 siswi kelas $\mathrm{X}, \mathrm{XI}, \mathrm{XII}$, dimana setiap kelompok berjumlah 30 responden. Data dianalisa dengan uji peringkat bertanda welcoxon, Uji $T$ berpasangan (T-Paired) dan regresi linier. Hasil penelitian ini menunjukan bahwa terdapat pengaruh penggunaan media video $(P v=0,024)$, leaflet $(P v=0,000)$ dan tanpa menggunakan media $(P v=0,003)$. Uji $F$ menunjukkan nilai $\mathrm{Pv}=0,005$, yang berarti ketiga variabel tersebut secara signifikan dapat untuk memprediksi variable efektifitas media. Promosi kesehatan dengan menggunakan media video dan leaflet sangat efektif begitu juga dengan tanpa menggunkan media (Video \& Leafleat).
\end{abstract}

Kata Kunci: Ca Mammae, deteksi dini, efektifitas, promosi kesehatan

\begin{abstract}
The incidence of cancer in Indonesia ranks 8th in Southeast Asia, while in Asia it is 23rd. The highest incidence rate in Indonesia for women is breast cancer, which is 42.1 per 100,000 population with an average death rate of 17 per 100,000. Early detection efforts that can be done to disseminate information are through health promotion methods. The purpose of this study was to determine the effectiveness of health promotion in early detection of Ca Mammae in adolescents by using video, leafleat and without media. The population in this study were students of SMKN 57, the total sample was 90 students of class $X, X I, X I I$, with each group of 30 respondents. The data were analyzed by means of the Welcoxon signed ranking test, paired $T$ test (T-Paired) and linear regression. The results of this study show that there is an effect of the use of video media $(P v=0,024)$, leaflets $(P v=0,000)$ and without using media $(P v=0,003)$. The $F$ test shows the value of $P v=0.005$, meaning that the three variables can significantly predict the variable effectiveness of the media. Health promotion using video media and leaflets is very effective as well as without using media (Video \& Leafleat).
\end{abstract}

Keywords: Breast cancer, early detection, effectiveness, health promotion 


\section{Pendahuluan}

Angka kejadian penyakit kanker di Indonesia sebanyak 136,2/100.000 penduduk, berada pada urutan ke-8 di Asia Tenggara dan urutan ke 23 di Asia. Angka kejadian untuk perempuan yang tertinggi adalah kanker payudara yaitu sebesar 42,1/100.000 penduduk dengan rata-rata kematian 17/100.000 penduduk yang diikuti kanker leher rahim yaitu sebesar 23,4/100.000 penduduk dengan rata-rata kematian 13,9/100.000 penduduk. ${ }^{1}$ Data Riskesdas, menyatakan bahwa, prevalensi tumor/kanker di Indonesia mengalami peningkatan dari 1.4 per 1000 penduduk di tahun 2013 menjadi 1,79 per 1000 penduduk pada tahun $2018 .^{2}$

Upaya yang dapat dilakukan untuk menyebarluaskan informasi $\mathrm{Ca}$ Mammae yaitu melalui metode promosi kesehatan. Media promosi kesehatan memiliki keunggulan dalam mengajak dan memberi informasi kepada siswi mengenai kanker payudara dan bagaimana cara mendeteksinya sejak dini. Media yang dapat mempengaruhi pengetahuan dan keterampilan untuk mendeteksi kanker payudara diantaranya leaflet dan vidio karena media tersebut dapat berfungsi untuk memperlancar pesan yang disampaikan oleh guru/promotor kesehatan. Kegunaan media adalah sebagai alat bantu untuk menyampaikan informasi sehingga pesan yang disampaikan akan lebih jelas dipahami, serta dapat mengatasi keterbatasan indera manusia, selain itu penyajian informasi akan dengan lebih dan menarik dibandingkan melalui bahasa verbal, sehingga diharapkan audiens lebih fokus dan tertarik dengan paparan informasi yang diberikan. ${ }^{3}$

Leaflet merupakan media yang disusun berdasarkan prinsip bahwa pengetahuan manusia diterima atau dapat ditangkap melalui panca indra. Leaflet yang baik menggunakan bahasa yang sederhana, mudah dimengerti, judul yang menarik serta dikombinasikan antara tulisan, gambar, dan materinya sesuai dengan target yang dituju. Penyebaran informasi melalui media leaflet merupakan salah satu cara untuk menyampaikan informasi kepada para wanita dan keluarganya atau mendukung informasi yang mereka terima. ${ }^{4}$

Larasati dalam penelitiannya menyatakan bahwa media promosi kesehatan dengan menggunakan video yoga lebih efektif dalam meningkatkan motivasi kesehatan wanita usia subur. ${ }^{5}$ Penelitian Melina menyatakan bahwa adanya pengaruh penggunaan media pembelajaran leaflet dan video terhadap keterampilan SADARI. ${ }^{6}$ Sifat masyarakat Indonesia sangat berpengaruh dengan individu lain, sehingga penting adanya motivasi dari pihak yang kuat untuk mengajak masyarakat sadar akan pentingnya kesehatan. ${ }^{6}$

Pada penelitian terdahulu promosi kesehatan dilakukan dengan menggunakan media dan intervensi dilakukan dengan tatap muka, namun pada penelitian ini dikarenakan keterbatasan untuk melakukan tatap muka, maka intervensi dilakukan melalui media whatsaap dengan tujuan untuk mengetahui efektifitas promosi kesehatan dalam deteksi dini Ca Mammae Pada Remaja dengan menggunakan video, leafleat dan tanpa media.

\section{Metode}

Desain penelitian ini adalah kuasi eksperimen yaitu kelompok pertama diberi promosi kesehatan dengan leaflet dan kelompok kedua diberi promosi kesehatan dengan video sedangkan kelompok ketiga tidak diberikan intervensi. Penelitian ini dilakukan di SMKN 57 pada bulan Agustus-September 2020. Populasi pada penelitian ini adalah siswi SMKN 57, jumlah sampel sebanyak 90 siswi kelas $\mathrm{X}, \mathrm{XI}, \mathrm{XII}$, dengan masing-masing kelompok berjumlah 30 responden.

Pengumpulan data terdiri dari 4 (empat) tahap yaitu, tahap pertama memberikan pre-test dengan menggunakan google form, tahap kedua membagi kelompok perlakuan yaitu kelompok promosi kesehatan dengan leaflet dan 
kelompok perlakuan dengan video melalui WhatsAap, tahap ketiga menyebarkan video, leaflet kepada kelompok melalui WhatsAap dan tahap keempat melakukan post-test pada masing-masing kelompok dengan menggunakan google form. Data yang digunakan dalam penelitian ini adalah data primer yaitu diberikan Pre dan Post test dengan menggunakan google form. Data dianalisa dengan uji peringkat bertanda welcoxon, Uji $\mathrm{T}$ berpasangan ( $T$ Paired) dan regresi linier.

\section{Hasil}

Pada data tabel 1 diketahui bahwa antara pre dan post-test dengan menggunakan media video diketahui bahwa terdapat penurunan (pengurangan) nilai antara pre dan post-test yaitu sebanyak 16 responden, sedangkan yang mengalami kenaikan nilai pre dan post-test sebanyak 10 responden dan sebanyak 4 responden yang memiliki nilai yang sama antara pre dan post-test dengan menggunakan media. Pada media leaflet diketahui bahwa sebanyak 24 responden yang mengalami penurunan antara nilai pre dan post tes sedangkan yang mengalami peningkatan nilai pre dan post tes sebanyak 5 responden dan yang memiliki nilai yang sama sebanyak 1 responden. Pada variabel kontrol diketahui bahwa sebanyak 19 responden yang mengalami penurunan nilai pre dan post-test sedangkan yang mengalami peningkatan nilai sebanyak 5 responden dan yang memiliki nilai yang sama sebanyak 6 responden. Selain itu dari hasil uji Wilcoxon (Tabel 2) dan Uji Paired T-test (Tabel 3) diketahui bahwa ada penggaruh penggunaan media video, leaflet dan tanpa medial terhadap pengetahuan responden.

Tabel 1. Hasil Uji Wilcoxon Rank Sum Test

\begin{tabular}{llccc}
\hline \multicolumn{2}{c}{ Variabel } & N & Mean Rank & Sum of Ranks \\
\hline & Negative Ranks & $16^{\mathrm{a}}$ & 16,50 & 264,00 \\
Pre dan Post Video & Positive Ranks & $10^{\mathrm{b}}$ & 8,70 & 87,00 \\
& Ties & $4^{\mathrm{c}}$ & & \\
& Total & 30 & & \\
& Negative Ranks & $24^{\mathrm{d}}$ & 16,85 & 404,50 \\
& Positive Ranks & $5^{\mathrm{e}}$ & 6,10 & 30,50 \\
Pre dan Post Leaflet & Ties & $1^{\mathrm{f}}$ & & \\
& Total & 30 & & \\
& Negative Ranks & $19^{\mathrm{g}}$ & 13,32 & 253,00 \\
Pre dan Post Kontrol & Positive Ranks & $5^{\mathrm{h}}$ & 9,40 & 47,00 \\
& Ties & $6^{\mathrm{i}}$ & & \\
& Total & 30 & & \\
\hline
\end{tabular}

Tabel 2. Hasil Uji Wilcoxon

\begin{tabular}{lccccc}
\hline \multicolumn{1}{c}{ Variabel } & \multicolumn{3}{c}{ N Ranks } & \multirow{2}{*}{ Z } & \multirow{2}{*}{ P-Value } \\
\cline { 2 - 4 } & Negatif & Positif & Ties & & \\
\hline $\begin{array}{l}\text { Pre-Post Pengetahuan Deteksi Dini Ca Mamae } \\
\text { pada kelompok Video }\end{array}$ & 10 & 16 & 4 & $-2,257$ & 0,024 \\
$\begin{array}{l}\text { Pre-Post Pengetahuan Deteksi Dini Ca Mamae } \\
\text { Pada kelompok kontrol }\end{array}$ & 5 & 19 & 6 & $-2,957$ & 0,003 \\
\hline
\end{tabular}

Tabel 3. Hasil Uji T Berpasangan (T-Paired)

\begin{tabular}{|c|c|c|c|c|c|c|c|c|}
\hline \multirow{3}{*}{$\begin{array}{c}\text { Pengetahuan Deteksi } \\
\text { Dini Ca Mamae pada } \\
\text { kelompok leafleat }\end{array}$} & \multicolumn{5}{|c|}{ Paired Differences } & \multirow{3}{*}{$\mathbf{t}$} & \multirow{3}{*}{ df } & \multirow{3}{*}{$\begin{array}{c}\text { Sig. (2- } \\
\text { tailed) }\end{array}$} \\
\hline & \multirow{2}{*}{ Mean } & \multirow{2}{*}{ SD } & \multirow{2}{*}{$\begin{array}{c}\text { SE } \\
\text { Mean }\end{array}$} & \multicolumn{2}{|c|}{$95 \% \mathrm{CI}$} & & & \\
\hline & & & & lower & upper & & & \\
\hline Pre-Post & $-10,733$ & 11,067 & 2,021 & $-14,866$ & $-6,601$ & $-5,312$ & 29 & 0,000 \\
\hline
\end{tabular}


Tabel 4. Pengaruh Media Video, Leaflet dan Kontrol (tanpa media) terhadap Pengetahuan Deteksi Dini Ca Mamae

\begin{tabular}{|c|c|c|c|c|c|c|c|c|c|}
\hline \multirow[t]{2}{*}{ Model } & \multicolumn{2}{|c|}{$\begin{array}{c}\text { Unstandardized } \\
\text { Coefficients }\end{array}$} & \multirow{2}{*}{$\begin{array}{c}\begin{array}{c}\text { Standardized } \\
\text { Coefficients }\end{array} \\
\text { Beta }\end{array}$} & \multirow[t]{2}{*}{ t } & \multirow[t]{2}{*}{ Sig. } & \multicolumn{2}{|c|}{$\begin{array}{c}\text { Collinearity } \\
\text { Statistics }\end{array}$} & \multirow{2}{*}{$\begin{array}{c}\mathbf{R} \\
\text { Square }\end{array}$} & \multirow{2}{*}{$\begin{array}{c}\mathbf{P} \\
\text { Value }\end{array}$} \\
\hline & $B$ & $S E$ & & & & Tolerance & VIF & & \\
\hline (Constant) & $-2,116$ & 0,745 & & $-2,839$ & 0,009 & & & & \\
\hline Post Video & 0,017 & 0,007 & 0,413 & 2,558 & 0,017 & 0,900 & 1,111 & 0,389 & 0,005 \\
\hline Post Leaflet & 0,008 & 0,005 & 0,232 & 1,488 & 0,149 & 0,963 & 1,038 & & \\
\hline Post Kontrol & 0,011 & 0,006 & 0,298 & 1,846 & 0,076 & 0,899 & 1,112 & & \\
\hline
\end{tabular}

Pada tabel 4 terlihat koefisien determinasi ( $R$-Square) menunjukkan nilai 0,389 artinya dari ketiga variabel tersebut dapat menjelaskan variasi efektifitas media sebesar 38,9\%. Kemudian pada uji $\mathrm{F}$ menunjukkan nilai $\mathrm{Pv}=0,005$, yang berarti bahwa ketiga variabel tersebut secara signifikan dapat untuk memprediksi variabel efektifitas media.

\section{Pembahasan}

Hasil penelitian ini diketahui bahwa terdapat pengaruh penggunaan media video, terhadap pengetahuan responden sehingga dapat dikatakan bahwa promosi dengan menggunakan media video sangat efektif dalam promosi kesehatan. Media promosi dengan menggunakan vidio merupakan kombinasi antara audio, visual dan animasi yang yang memiliki pesan tertentu sehingga diharapkan menjadi daya tarik tersendiri atau bisa bersifat persuasif bagi responden. Media video pembelajaran merupakan seperangkat komponen yang mampu menampilkan gambar sekaligus suara dalam waktu bersamaan. ${ }^{7}$ Video pembelajaran merupakan media yang digunakan untuk mentransfer pengetahuan serta juga dapat digunakan sebagai bagian dari proses belajar. Menggunakan media vidio akan lebih interaktif dan spesifikasi dari sebuah buku atau kuliah. Tutorial media vidio memberikan pengajaran dengan contoh dan memberikan informasi untuk menyelesaikan tugas tertentu. ${ }^{7}$

Penelitian ini sejalan dengan hasil penelitian Larasati yang menyatakan bahwa penggunaan media promosi kesehatan video yoga efektif dalam meningkatkan motivasi kesehatan wanita usia subur. ${ }^{5}$ Begitu juga dengan hasil penelitian Melina yang menyatakan bahwa terdapat pengaruh penggunaan media pembelajaran leaflet dan video terhadap keterampilan SADARI. ${ }^{5}$

Pada penelitian ini menunjukan bahwa terdapat pengaruh penggunaan media leaflet terhadap pengetahuan responden, sehingga dapat disimpulkan bahwa promosi dengan menggunakan media leaflet sangat efektif dalam promosi kesehatan. Leaflet merupakah salah satu bentuk media cetak yang berisikan rangkuman suatu promosi. Isi suatu promosi tersebut diambil dari beberapa sumber buku maupun internet yang dijadikan dalam bentuk leaflet. Leaflet didesain secara cermat dan dilengkapi dengan ilustrasi dengan menggunakan bahasa yang mudah dimengerti, singkat dan mudah dipahami. Kelebihan dari bahan ajar cetak leaflet adalah tidak diperlukannya alat yang khusus dan mahal untuk memanfaatkannya. ${ }^{8}$ Leaflet merupakan salah satu bahan ajar yang baik dalam hal mengembangkan kemampuan siswa untuk belajar tentang fakta dan mengerti prinsip-prinsip umum dengan menggunakan argumentasi yang logis. ${ }^{8} \mathrm{Hal}$ ini sejalan sejalan dengan hasil penelitian guru kelas Sekolah Dasar Negeri Sewar yang menyatakan bahwa penggunaan media leaflet dapat meningkatkan hasil belajar siswa kelas V SDN Sewar kecamatan Pujut. ${ }^{9}$

Hasil penelitian Gani menyebutkan bahwa terdapat perbedaan pengetahuan, sikap dan praktik pencegahan HIV/AIDS sebelum dan sesudah dilakukan intervensi melalui media leaflet dan poster produk 
Komisi Penanggulangan AIDS Kabupaten Jember. Dari hasil penelitian tersebut juga diketahui adanya perbedaan efektivitas antara menggunakan media leaflet dan poster dalam upaya meningkatkan perilaku pencegahan HIV/AIDS, penelitian tersebuut juga menunjukan bahwa media leaflet lebih efektif dalam meningkatkan pengetahuan, sikap dan praktik pencegahan HIV/AIDS dibandingkan media poster. ${ }^{10}$

Pada penelitian ini diketahui bahwa terdapat pengaruh promosi kesehatan deteksi dini ca maammae tanpa menggunakan media video maupun leaflet terhadap pengetahuan remaja. Hasil penelitian ini berbeda dengan hasil penelitian Shorea yang menyatakan bahwa tidak ada perbedaan antara pengetahuan remaja putri tentang SADARI sebelum dan sesudah tanpa diberikan promosi kesehatan tentang SADARI pada kelompok kontrol. ${ }^{11}$ Hal ini dimungkinan karena semakin mudahnya kalangan remaja mengakses Media Sosial seperti Whatsapp, BBM, Facebook, Youtube, Twitter, Wikipedia, dan Blog. Media sosial tersebut memudahkan remaja untuk mengakses informasi/promosi kesehatan dengan menggunakan teknologi berbasis web yang mengubah komunikasi menjadi dialog interaktif. Teknologi informasi telah berkembang sedemikian pesat sehingga mempermudah kinerja manusia dalam mengolah data yang merupakan sebuah teknologi yang terkait dalam pengolahan informasi. Perkembangan teknologi informasi telah memiliki peranan yang sangat penting pada bidang promosi kesehatan. Promosi kesehatan jika didukung oleh teknologi informasi yang baik dan benar dalam pemanfaatannya akan memberikan sumber informasi yang baik dan efektif.

Hasil penelitian Sherlyanti diketahui bahwa siswa SMPN 52 Surabaya sebagian besar dapat menggunakan internet secara baik, dalam hal penggunaan sebagai sarana pembelajaran ataupun fungsi hiburan.. Waktu interaksi siswa antara interaksi langsung di kehidupan sehari-hari dan media sosial sudah seimbang dan sesuai dengan porsinya. Dari hasil penelitian tersebut juga diketahui bahwa para siswa dapat mengetahui hal-hal dasar pada keamanan, seperti pembatasan privasi dan sharing untuk orang yang dikenal. ${ }^{12}$

Promosi kesehatan dengan menggunakan media video dan leaflet sangat efektif begitu juga dengan tanpa menggunakan media video dan leafleat. Hal ini kemungkinan dipengaruhi oleh mudahnya para remaja mengakses internet dan menggunakan sosial media sehingga diharapkan promosi kesehatan tidak hanya terbatas dengan menggunakan media video dan leafleat saja namun, dapat juga menggunakan sosial media yang populer di kalangan remaja seperti Whatsapp, Line, BBM, Facebook, Youtube, Twitter, Wikipedia, dan Blog.

\section{Kesimpulan}

Hasil penelitian ini diketahui bahwa penggunaan media video, leaflet dan tanpa menggunakan media terbukti efektif dalam meningkatkan pengetahuan remaja terkait deteksi dini ca. mammae. Diharapkan promosi kesehatan selain menggunakan media video dan leaflet juga menggunakan sosial media yang familiar di kalangan remaja seperti Whatsapp, Line, BBM, Facebook, Youtube, Twitter, Wikipedia, dan Blog. Pada Penelitian berikutnya diharapkan melakukan penelitian yang serupa dengan karakteristik yang berbeda sehingga diketahui efektifitas promosi kesehatan melalui media video dan lefleat.

\section{Daftar Pustaka}

1. Kemenkes RI. Penyakit kanker di Indonesia berapa pada urutan 8 di Asia tenggaran dan urutan 23 di Asia. Diakses dari Available at: http://p2p.kemkes.go.id/penyakit-kanker-diindonesia-berada-pada-urutan-8-di-asiatenggara-dan-urutan-23-di-asia/__[Diakses 1 Maret 2020].

2. Riset Kesehatan Dasar (Riskesdas). Badan Penelitian dan. Pengembangan Kesehatan Kementerian RI tahun 2018.

3. Susilana CR. Media Pembelajaran. Bandung: CV Wacana Prima; 2011.

4. Yulianti D. Promosi Kesehatan Dalam Praktik Kebidanan. Jakarta: EGC; 2011 
5. Larasati DE. Efektifitas Penggunaan Media Promosi Kesehatan Video Yoga Dalam Meningkatkan Motivasi Kesehatan Wanita Usia Subur Tentang Kesehatan Reproduksinya. VI(2), 2015. pp. 88-11.

6. Melina F. Perbedaan Media Pembelajaran (Leafleat dan Video) Terhadap Keterampilan SADARI ditinjau Dari Motovasi. Jurnal Kesehatan Samodra Ilmu; 2014.

7. Sukiman. Pengembangan Media Pembelajaran. Yogyakarta: Pedagogia; 2012.

8. Solong NP. Pengembangan Materi Pendidikan Agama Islam. Yogyakarta: Teras; 2014.

9. Tengah GK. Meningkatkan Hasil Belajar IPA Materi Sistem Pencernaan Manusia Dengan Bahan Ajar Leafleat Pada Siswa Kelas V SDN Sewar Tahun Pelajaran 2018-2019. Ilmu
Sosial dan Pendidikan, IV(1); 2020.

10. Ghani AH. Perbedaan Efektifitas Leafleat dan Poster Produk Komisi Penanggulangan AIDS Kabupaten Jember Dalam Perilaku Pencegahan HIV/AIDS. X(1), 2014. pp. 3148.

11. Shorea D. Efektifitas Promosi Kesehatan Melalui Audio Visual Tentang Pemeriksaan Payudara Sendiri (SADARI) Terhadapat Peningkatan Pengetahuan Remaja Putri. UNRI; 2013.

12. Sherlyanti AK. Pengaruh dan Pola Aktivitas Penggunaan Internet Serta Media Sosial pada Siswa SMPN 52 Surabaya. Information Syistem Engineering and Business Intelligence, II(1), 2016. pp. 17-22. 